\title{
Inhibition of Ethylene Biosynthesis and Action in Cut Carnations (Dianthus caryophyllus L.) by Aminotriazole
}

\author{
Steven A. Altman ${ }^{1}$ and Theophanes Solomos \\ Department of Horticulture, University of Maryland, College Park, MD 20742
}

Additional index words. 1-aminocyclopropane-1-carboxylic acid (ACC), ACC synthase, aminotriazole, cut flowers, senescence

\begin{abstract}
Treating 'Elliott's White' cut carnations with 50 or $100 \mathrm{~mm}$ aminotriazole for 4 days inhibits the respiratory climacteric and significantly extends vase life. Aminotriazole induced time- and concentration-dependent inhibition of ethylene evolution and onset of the ethylene climacteric by inhibiting ACC synthase activity. Flowers treated with 50 or $100 \mathrm{~mm}$ aminotriazole for 2 days exhibited concentration-dependent increases in ethylene evolution, respiratory activity, ACC synthase activity, and petal ACC content in response to the application of exogenous ethylene at $10 \mu \mathrm{l} \cdot \mathrm{liter}^{-1}$. Senescence-associated morphological changes, increased ACC synthase activity, ACC content, and ethylene evolution were completely inhibited in flowers treated for 4 days with $100 \mathrm{~mm}$ aminotriazole. Although treatment with $50 \mathrm{~mm}$ aminotriazole for 4 days did not completely inhibit components of the ethylene biosynthetic pathway, no morphological or respiratory responses to the application of exogenous ethylene at $10 \mu \mathrm{l} \cdot \mathrm{liter}^{-1}$ were observed, a result indicating that prolonged aminotriazole treatment inhibited ethylene action. Chemical names used: 3-1H-amino-1,2,4-triazole-1-yl (aminotriazole), 1-aminocyclopropane-1-carboxylic acid (ACC).
\end{abstract}

Despite recent advances in understanding the regulation of ripening and senescence (Oeller et al., 1991), developmental signals leading to expression of ACC synthase, the nature of the ethylene receptor, the molecular basis of the signal transduction pathway culminating in ethylene action, and the role of ethylene action in senescence are unknown. Aminotriazole, a low-molecular-weight heterocyclic ring compound used as a postemergence, nonselective, systemic herbicide (Sine et al., 1991), may be useful in identifying the molecular species involved in ethylene-receptor interaction or signal transduction of ethylene action. The effects of aminotriazole on cellular metabolism include inhibition of peroxisomal assembly of tetrameric catalase apoenzyme (Reid et al., 1981), $\mathrm{CO}_{2}$ assimilation (Amory et al., 1992), mitochondrial protein biosynthesis, and imidazolglycerol-phosphate dehydratase, an enzyme of histidine biosynthesis in bacteria and fungi (Kidd and Gross, 1984). However, aminotriazole is not a nonspecific metabolic poison, since it does not inhibit enzymes such as ascorbate peroxidase and glutathione reductase (Amory et al., 1992). Goatley and Schmidt (1990) reported that two systemic triazole fungicides, tridimefon and propiconizole, have anti-senescence properties in small grains and Kentucky bluegrass. The chemical moiety these compounds share with aminotriazole is the $1 \mathrm{H}-1,2,4$-triazole heterocyclic ring, a characteristic implying that this structure may account for the observed effects on senescence. We previously reported that continuous postharvest treatment of carnations with 50 or $100 \mathrm{~mm}$ aminotriazole results in a significant extension of useful vase life, suppressed respiration, inhibition of the climacteric rise in $\mathrm{CO}_{2}$, and differential time- and concentration-dependent floral responses to exogenous ethylene (Altman and Solomos,

Received for publication 7 June 1993. Accepted for publication 17 Aug. 1993. We thank Lisa Randers for assistance with manuscript preparation. Mention of a trademark, proprietary product, or vendor does not constitute a guarantee or warranty of the product nor imply its approval by the Univ. of Maryland or its affiliates to the exclusion of other products or vendors that also may be suitable. The cost of publishing this paper was defrayed in part by the payment of page charges. Under postal regulations, this paper therefore must be hereby marked advertisement solely to indicate this fact.

${ }^{1}$ Present address: Dept. of Chemical and Biochemical Engineering, Univ. of Maryland Baltimore County, 255 Technology Research Center, 5200 Westland Blvd., Baltimore, MD 21227.
1993). We report here that aminotriazole inhibited ethylene biosynthesis by inhibiting ACC synthase biosynthesis and that the inhibition of ethylene action by aminotriazole was temporally mediated.

\section{Materials and Methods}

Plantmaterial and aminotriazole treatment. White Sim 'Elliott's White' carnations were obtained from Univ. of Maryland greenhouses. Physiologically uniform flowers were produced by date tagging individual blooms at petal break. Twelve identically dated flowers of uniform size, appearance, and quality, with petals reflexed $90^{\circ}$ relative to the stem were used in each experiment. Flowers with a stem length $\geq 45 \mathrm{~cm}$ were harvested in the morning and placed in darkness for $2 \mathrm{~h}$ at $18 \mathrm{C}$ to achieve thermal equilibrium. Physiological uniformity of the sample was checked by measuring the respiratory activity of individual flowers. Deviant flowers were replaced.

Stems were shortened to $25 \mathrm{~cm}$ and immediately placed into $1000-\mathrm{ml}$ foil-covered beakers containing $250 \mathrm{ml}$ of 50 or $100 \mathrm{~mm}$ aminotriazole or distilled $\mathrm{H}_{2} \mathrm{O}\left(\mathrm{dH}_{2} \mathrm{O}\right)$. After $2 \mathrm{~h}$ of treatment, stems were shortened to $7.0 \mathrm{~cm}$. Flowers were then weighed and transferred to individual 25-ml Erlenmeyer flasks containing either $20 \mathrm{ml}$ of freshly prepared aminotriazole solution of identical concentration or $\mathrm{dH}_{2} \mathrm{O}$. After 2 or 4 days of aminotriazole treatment, all flowers were transferred to flasks containing $20 \mathrm{ml}$ of $\mathrm{dH}_{2} \mathrm{O}$.

Respiratory activity and ethylene measurement. Flowers were kept for respiratory monitoring in a temperature-controlled gasflow incubation chamber at $18 \mathrm{C}$ in darkness. Individual flowers were sealed in 950-ml glass jars connected to a common supply of breathing-quality air through a splitter manifold. The $\mathrm{CO}_{2}$ content in the outlet stream from each jar was monitored by an automatic sampling device connected to a dual-channel infrared gas analyzer (model AR-600R; Anarad, Santa Barbara, Calif.). Mean gas flow was maintained at $50 \mathrm{ml} \cdot \mathrm{min}^{-1}$. Ethylene evolution rates were monitored on a gas chromatograph (model 5480A; Hewlett-Packard, Avondale, $\mathrm{Pa}$.) equipped with a flame ionization detector and fitted with a $125 \times 0.32-\mathrm{cm}$ stainless-steel column packed with 75 - 
to 100-mesh activated $\mathrm{Al}_{2} \mathrm{O}_{3}$

The effect of aminotriazole on ethylene action was determined by exposing treated flowers to exogenous ethylene at $10 \mu l \cdot$ liter $^{-1}$. After 2 days of aminotriazole treatment and transfer to $\mathrm{dH}_{2} \mathrm{O}$, flowers were exposed to ethylene for $36 \mathrm{~h}$ and then returned to air. Flowers treated with aminotriazole for 4 days were exposed to ethylene at $10 \mu \mathrm{l} \cdot \mathrm{liter}^{-1}$ either immediately after transfer to $\mathrm{dH}_{2} \mathrm{O}$ or at the onset of the respiratory climacteric in control flowers. Such flowers were exposed to ethylene for $96 \mathrm{~h}$ and returned to air. All experiments were conducted four times.

ACC synthase extraction and assay. The effect of aminotriazole on the ethylene biosynthetic pathway was determined by measuring changes in the maximal extracted activity of ACC synthase and in the concentration of ACC in petals of flowers treated for 2 or 4 days with 50 or $100 \mathrm{~mm}$ aminotriazole. Six replicate flowers were assayed for ACC synthase activity and ACC content. Petals were excised, weighed, and divided into equal aliquots for ACC synthase and ACC extraction.

ACC synthase extraction was performed according to Peiser (1986), incorporating modifications suggested by Hyodo and Fujinami (1989) and Hyodo et al. (1990). Petal tissues were homogenized in a minimal volume of ice cold extraction buffer [150 mM HEPES, pH 8.5, $10 \mathrm{~mm}$ dithiothreitol (DTT), and 5.0 $\mu \mathrm{M}$ pyridoxal-5'-phosphate (PLP)]. Clarified supernatant was dialyzed for $24 \mathrm{~h}$ at $4 \mathrm{C}$ against three changes of 50 times the sample volume of dialysis buffer (10 mм HEPES, pH 8.5, 1.0 mм DTT, and $1.0 \mu_{\mathrm{M}}$ PLP).

Dialyzed supernatant was assayed for ACC synthase activity in $600 \mu \mathrm{l}$ total reaction volume (Yu et al., 1979). Reaction mixtures contained 50 mм HEPES, pH 8.5, $50 \mu \mathrm{m} S$-adenosylmethionine (SAM), 5.0 $\mu \mathrm{M}$ PLP, and $400 \mu \mathrm{l}$ sample extract. Reaction tubes were incubated at $30 \mathrm{C}$ for $3 \mathrm{~h}$. Reaction mixture internal controls were prepared by replacing SAM with $1.0 \mathrm{nmol}$ ACC in replicate aliquots of dialyzed supernatant. ACC formation was measured according to Lizada and Yang (1979). ACC synthase activity was expressed in units, defined as the amount of enzyme that produced $1.0 \mu \mathrm{mol}$ ethylene/g fresh weight (FW) tissue per min.

ACC extraction and assay. Petal tissues were homogenized in ice-cold $10 \%$ (by volume) $\mathrm{HClO}_{4}$ and centrifuged at $10,000 \times g$. Pellets were reextracted in 0.5 volume $\mathrm{HClO}_{4}$ and the supernatants were combined. Columns of 1.0-ml bed volume filled with a strong cation-exchange resin (Dowex 50W-X4, 50 to 100 dry mesh; BioRad Laboratories, Richmond, Calif.) were washed once with $1.0 \mathrm{~N}$ $\mathrm{HCl}$ followed by $\mathrm{dH}_{2} \mathrm{O}$ until the eluate reached $\mathrm{pH}$ 6.0. Sample extract equivalent to $\approx 1.0 \mathrm{~g} \mathrm{FW}$ tissue was loaded onto the column and the column was washed with $2 \mathrm{x}$ sample volume of $\mathrm{dH}_{2} \mathrm{O}$. ACC was eluted with $1.0 \mathrm{~N} \mathrm{NaOH}$. Internal controls were prepared by adding $1.0 \mathrm{nmol}$ ACC to replicate aliquots of sample and loading them onto additional columns. A 2.0-ml sample was collected from all columns as the eluate reached $\mathrm{pH}$ 8.0. The conversion of ACC to ethylene was performed as described (Lizada and Yang, 1979). Samples were held on ice for $1 \mathrm{~h}$ before removing $2.0 \mathrm{ml}$ of head-space gas for ethylene determination. ACC content was expressed as nanomoles of ACC per gram FW tissue.

\section{Results}

Ethylene evolution and action. Although the climacteric increase in ethylene evolution was not inhibited in flowers treated for 2 days with either 50 or $100 \mathrm{~mm}$ aminotriazole, time to the onset of the ethylene climacteric was delayed and peak values of ethylene evolution were lower relative to control flowers. The delay to the onset of peak ethylene evolution was concentration-dependent
(Fig. 1a). No increase in ethylene evolution was observed in flowers treated with $100 \mathrm{~mm}$ aminotriazole for 4 days (Fig. 1b). Treatment with $50 \mathrm{~mm}$ aminotriazole for 4 days did not completely inhibit ethylene evolution, but onset of the ethylene increase was delayed and peak ethylene values were 2 -fold lower than in flowers treated with $50 \mathrm{~mm}$ aminotriazole for 2 days (Fig. 1b).

The effect of aminotriazole on ethylene-enhanced respiration was temporally mediated in that the magnitude of the respiratory response depended on the length of aminotriazole treatment before exposure to exogenous ethylene. Flowers treated for 2 days with either 50 or $100 \mathrm{~mm}$ aminotriazole exhibited an increase in respiration indistinguishable from that of controls in response to ethylene at $10 \mu \mathrm{l} \cdot \mathrm{liter}^{-1}$ for $36 \mathrm{~h}$ (Fig. 2) and senescence-associated morphological changes (Altman and Solomos, 1993). In contrast, no increase in respiration was elicited in flowers treated with ethylene at $10 \mu \mathrm{l} \cdot \mathrm{liter}^{-1}$ for $96 \mathrm{~h}$ after 4 days of treatment with either 50 or $100 \mathrm{~mm}$ aminotriazole, independent of the time postharvest of ethylene treatment (Fig. 3). Similarly, no senescence-associated morphological changes occurred in flowers treated for 4 days with either concentration of aminotriazole (Altman and Solomos, 1993).

Petal ACC synthase and ACC content. In parallel with changes in ethylene evolution observed in treated flowers, aminotriazole inhibition of whole-petal ACC synthase activity and ACC content was time- and concentration-dependent. Petal ACC synthase activity was inhibited by $41 \%$ and $74 \%$ of the peak value of untreated

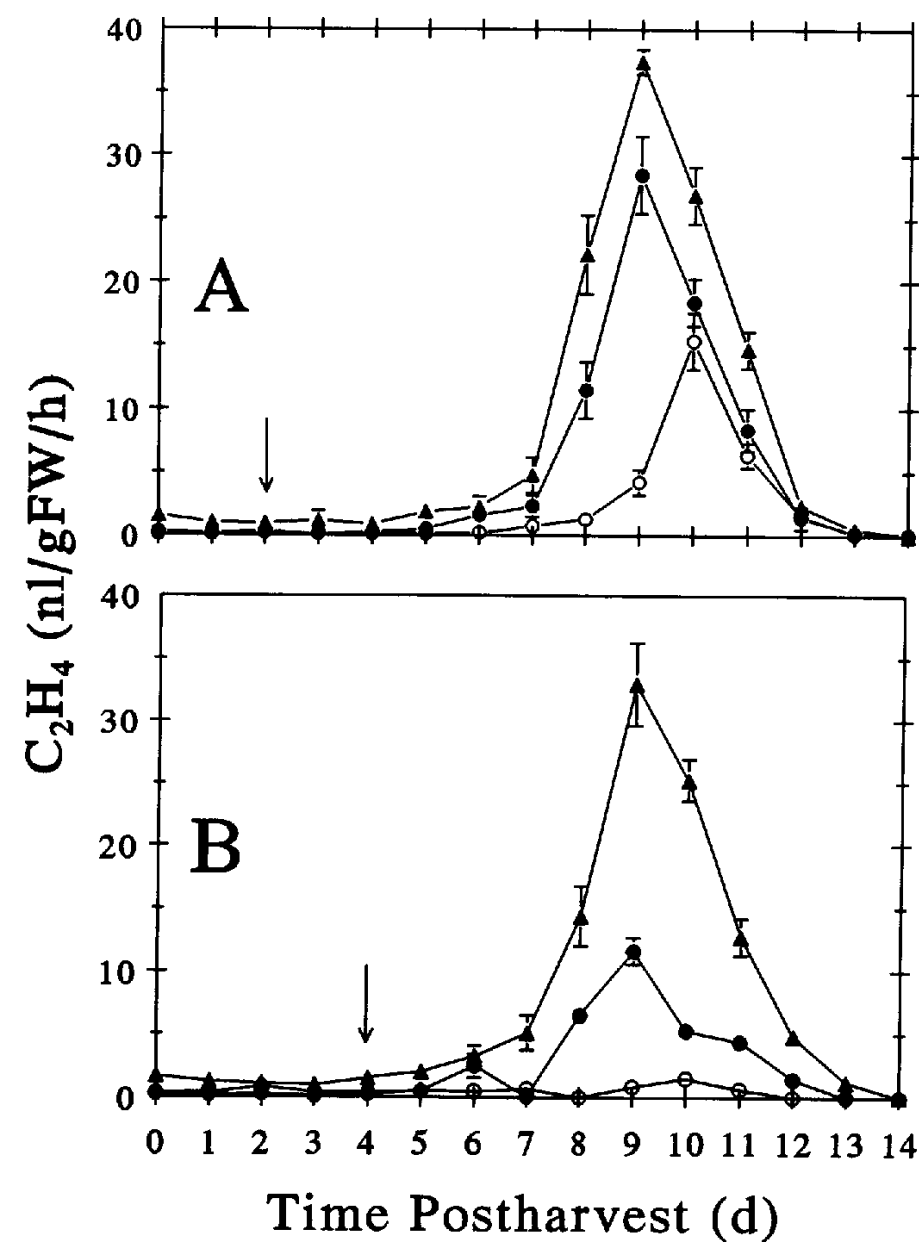

Fig. 1. Ethylene evolution of cut carnations treated with $50 \mathrm{~mm}$ aminotriazole $(\mathbf{O}), 100$ mM aminotriazole $(\mathrm{O})$, or distilled $\mathrm{H}_{2} \mathrm{O}\left(\mathrm{dH}_{2} \mathrm{O}\right)(\boldsymbol{\Delta})$ for 2 days $(\mathbf{A})$ or 4 days $(\mathbf{B})$ postharvest followed by transfer to $\mathrm{dH}_{2} \mathrm{O}$. Arrows indicate time of transfer of treated flowers to $\mathrm{dH}_{2} \mathrm{O}$. Bars at each data point represent \pm 1 SE of the mean. 


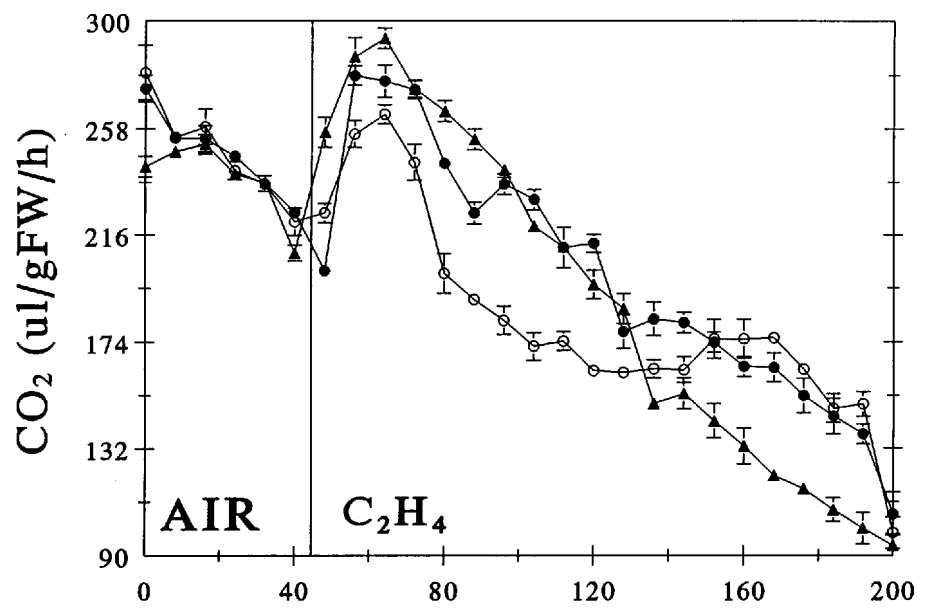

Time Postharvest (h)

Fig. 2. Respiratory activity of cut carnations treated with $50 \mathrm{~mm}$ aminotriazole $(\bullet)$, $100 \mathrm{~mm}$ aminotriazole $(\mathrm{O})$, or distilled $\mathrm{H}_{2} \mathrm{O}\left(\mathrm{dH}_{2} \mathrm{O}\right)(\boldsymbol{\Delta})$ for 2 days postharvest followed by transfer to $\mathrm{dH}_{2} \mathrm{O}$ and immediate exposure to ethylene at $10 \mu \mathrm{l} \cdot$ liter ${ }^{1}$. Bars represent $\pm 1 \mathrm{sE}$.

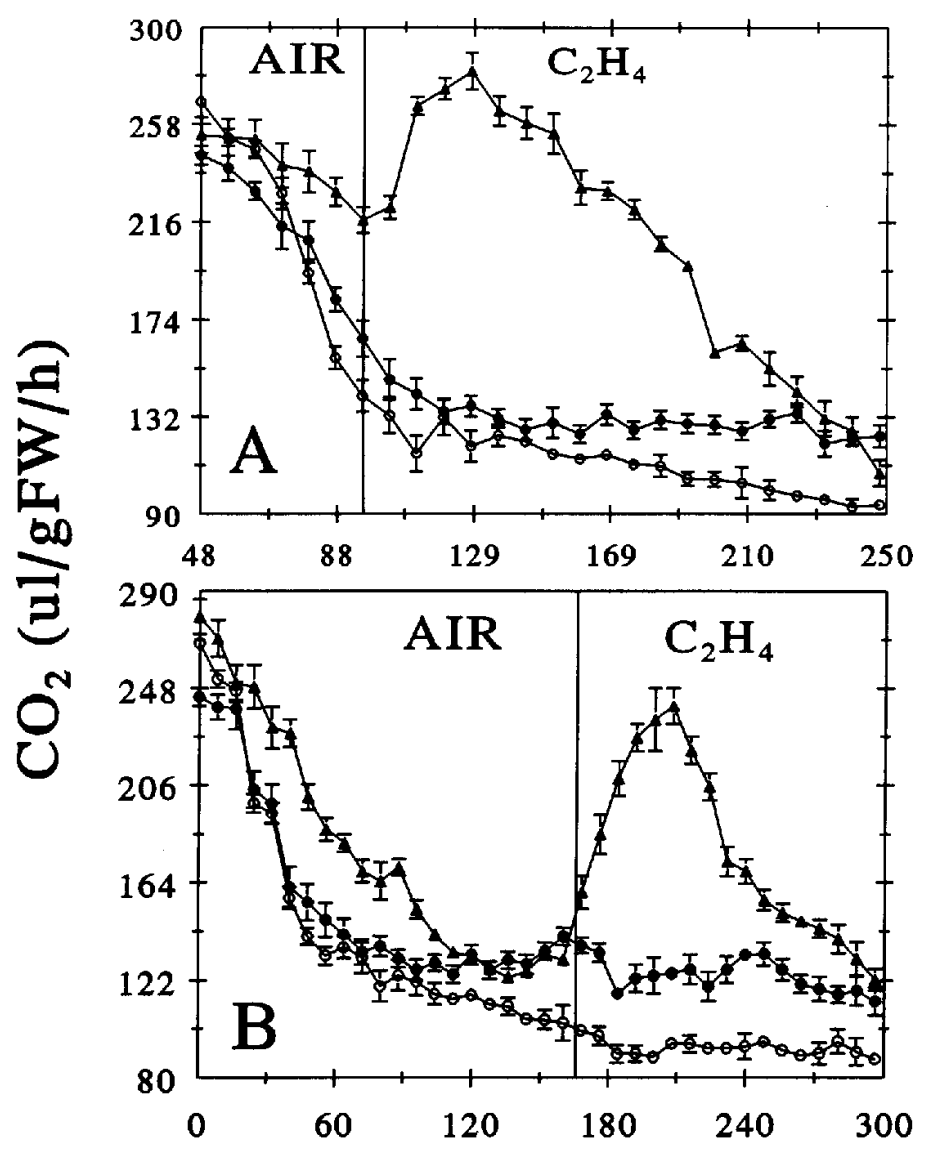

\section{Time Postharvest (h)}

Fig. 3. Respiratory activity of cut carnations treated with $50 \mathrm{~mm}$ aminotriazole $(\mathbf{O})$, $100 \mathrm{~mm}$ aminotriazole $(\mathrm{O})$, or with distilled $\mathrm{H}_{2} \mathrm{O}\left(\mathrm{dH}_{2} \mathrm{O}\right)(\boldsymbol{\Delta})$ for 4 days postharvest followed by transfer to $\mathrm{dH}_{2} \mathrm{O}$ and exposure to ethylene at 10 $\mu 1 \cdot \operatorname{liter}^{-1}$ (A) immediately or (B) at the onset of the climacteric in $\mathrm{dH}_{2} \mathrm{O}$-treated control flowers. Bars represent \pm 1 SE. controls in flowers treated for 2 days with 50 or $100 \mathrm{~mm}$ aminotriazole, respectively (Fig. 4a). Similarly, ACC content was inhibited by $46 \%$ and $79 \%$ of the peak value of controls in flowers treated for 2 days with 50 or $100 \mathrm{~mm}$ aminotriazole, respectively (Fig. 4c). No increase in ACC synthase activity (Fig. 4b) or in ACC content (Fig. 4d) was observed for 9 days postharvest in petals of flowers treated with $100 \mathrm{~mm}$ aminotriazole for 4 days. However, treating flowers for 4 days with $50 \mathrm{~mm}$ aminotriazole inhibited ACC synthase activity by $76 \%$ of the peak value of untreated controls (Fig. 4b). ACC content was similarly inhibited by $69 \%$ of the controls (Fig. 4d). The increase in ACC synthase and ACC in flowers treated with $50 \mathrm{~mm}$ aminotriazole for 4 days occurred concomitant with the climacteric increase in ethylene evolution of the controls (Fig. 1) but in the absence of any senescence-associated morphological changes (Altman and Solomos, 1993). As expected, the rate of ethylene evolution (Fig. 1) and ACC synthase activity (Fig. 4) decreased while petal ACC content increased (Peiser, 1986). This result may indicate that the activity of ACC oxidase decreases after the peak of ACC synthase activity (Ververidis and John, 1991) or that ACC is sequestered into vacuoles (Saftner and Martin, 1993).

The onset of increased ACC synthase activity and ACC accumulation was also delayed by aminotriazole application. ACC synthase activity and ACC content of untreated controls increased 24 to $48 \mathrm{~h}$ before the climacteric increase in ethylene evolution and 48 to $72 \mathrm{~h}$ before the climacteric ethylene peak. Increased ACC synthase activity and ACC content of aminotriazole-treated flowers were delayed by an additional 24 to $72 \mathrm{~h}$ relative to the controls. The length of the lag period depended on aminotriazole concentration and length of time in treatment (Fig. 4).

ACC synthase activity and ACC content of flowers treated with $50 \mathrm{~mm}$ aminotriazole for 2 days followed by exposure to ethylene at $10 \mu \mathrm{l} \cdot$ liter $^{-1}$ were similar to that of untreated controls (Figs. $5 \mathrm{a}$ and c). However, petal ACC synthase activity and ACC content were respectively inhibited by $40 \%$ and $47 \%$ of the peak value of untreated controls in flowers exposed to ethylene after treatment for 2 days with $100 \mathrm{~mm}$ aminotriazole (Fig. $5 \mathrm{a}$ and c). No increase in ACC synthase activity (Fig. 5b) or petal ACC content (Fig. 5d) was observed for 10 days postharvest in flowers treated with 100 $\mathrm{mm}$ aminotriazole for 4 days and exposed to ethylene at 10 $\mu \mathrm{l} \cdot$ liter $^{-1}$. In contrast, 4 days treatment with $50 \mathrm{~mm}$ aminotriazole did not completely inhibit ACC synthase activity (Fig. 5b) or ACC accumulation (Fig. 5d) in the petals after exposing the treated flowers to ethylene. Although ACC synthase activity declined before the peak of ACC accumulation, activity was still measurable 10 days postharvest (Figs. $5 \mathrm{a}$ and b, inserts).

\section{Discussion}

Although the varied biochemical, biophysical, and molecular changes associated with plant senescence require the constant presence of a low concentration of ethylene (Sisler and Lallu, 1993), carnation petal wilting occurs in synchronous response to a primary triggering event such as increased ethylene evolution (Yang, 1985; Solomos, 1988; Woodson and Lawton, 1988). Ethylene regulates the respiratory climacteric and subsequent biochemical changes associated with fruit ripening and floral senescence (Abeles et al., 1992). The pivotal role of ACC synthase in fruit ripening was recently demonstrated in studies showing that tomato ripening is inhibited by antisense mRNA suppression of ACC synthase (Oeller et al., 1991; Theologis et al., 1992).

Sensitivity to ethylene increases during aging in plant tissues (Trewavas, 1982). Although many flowers and fruit produce a low 

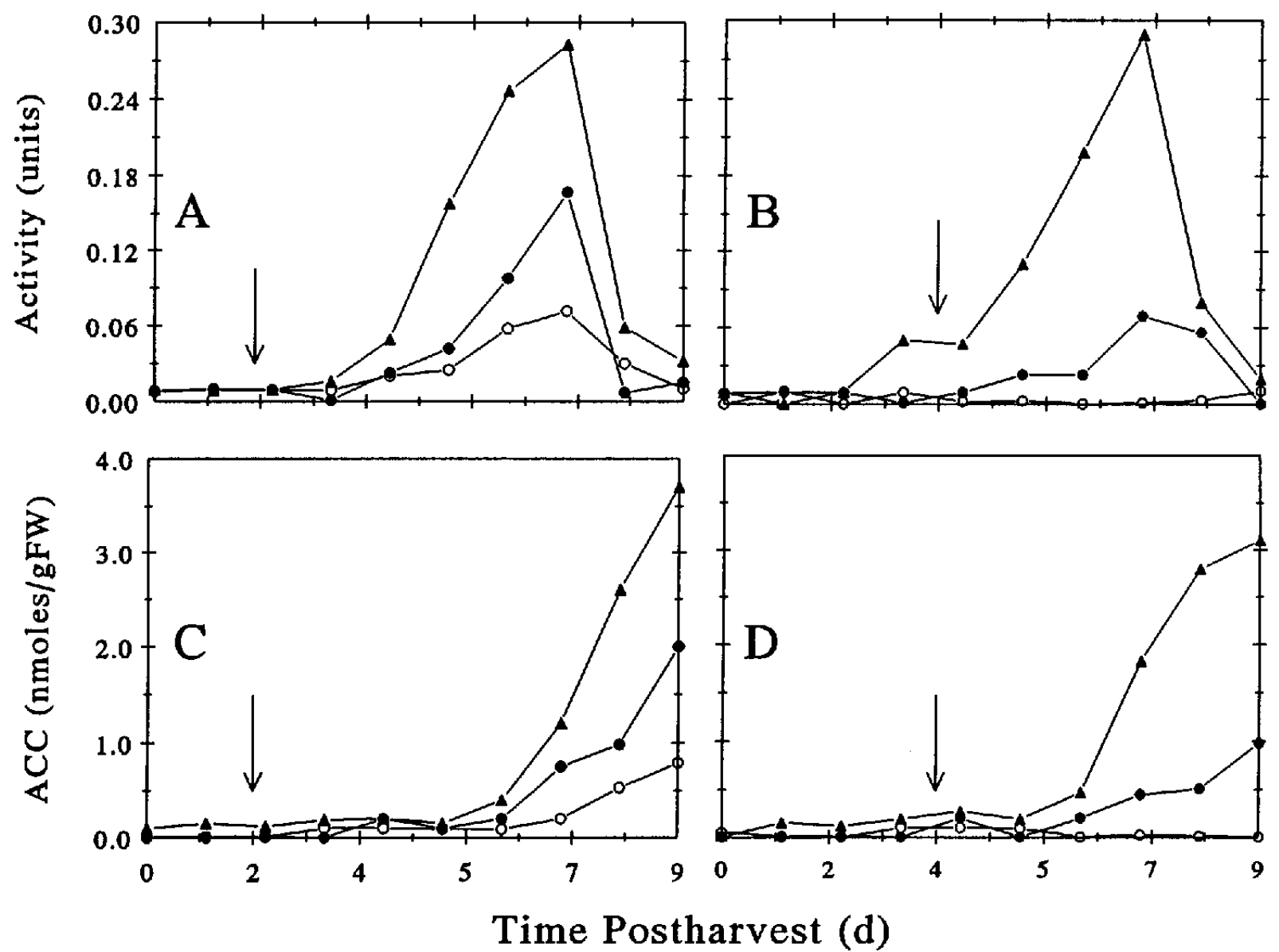

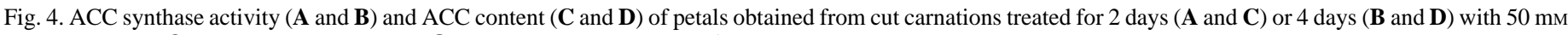
aminotriazole $(\mathbf{O}), 100 \mathrm{~mm}$ aminotriazole $(\mathrm{O})$, or distilled $\mathrm{H}_{2} \mathrm{O}\left(\mathrm{dH}_{2} \mathrm{O}\right)(\mathbf{\Delta})$. Arrows indicate the time of transfer of treated flowers to d $\mathrm{H}_{2} \mathrm{O}$.

concentration of ethylene during the preclimacteric (McMurchie et al., 1972), it is not clear whether this amount of ethylene enhances sensitivity of the tissue to ethylene action or if additional developmental processes, such as an increase in ethylene receptor molecules or in transducers of ethylene action (Van Loon and Bruinsma, 1992), are required to enhance the receptivity of the tissue to ethylene. In the present study, aminotriazole prolonged carnation vase life by inhibiting ethylene biosynthesis through time- and concentration-dependent inhibition of ACC synthase and therefore of the subsequent ACC synthase-catalyzed conversion of SAM to ACC (Figs. 4 and 5). Hormonal effects are contingent on hormone perception through binding at a receptor site and subsequent signal transduction (Van Loon and Bruinsma, 1992). However, the stochastic nature of hormonal regulation in plants (Trewavas, 1991) creates difficulties in identifying physiological or molecular causes of whole-plant responses to hormonal stimuli. Recent studies using ethylene-insensitive mutants have demonstrated that observed pleiotropic responses to endogenous ethylene originate from a single gene product, which may be an ethylene receptor (Bleeker et al., 1988). Although antisense inhibition of an ACC oxidase-related protein, E8, results in ethylene overproduction in ripening tomatoes (Peñarrubia et al., 1992), time- and concentration-dependent inhibition of ethylene-mediated responses and incomplete inhibition of ethylene biosynthesis by aminotriazole indicates that inhibition of components of the ethylene biosynthetic pathway and of subsequent ethylene action were the primary modes of action of the compound in inhibiting floral senescence.
Although the in vitro effect of aminotriazole on ACC synthase activity was not ascertained, the in vivo effects of aminotriazole treatment indicate that the compound did not directly inhibit the catalytic activity of ACC synthase. For example, ACC synthase activity and subsequent ethylene evolution were not inhibited by 2 days of treatment with either concentration of aminotriazole (Fig 1a) or by 4 days of treatment with $50 \mathrm{~mm}$ aminotriazole (Fig. 1b). Since previous studies have demonstrated more rapid and complete aminotriazole-mediated inhibition of target enzymes (Amory et al., 1992; Ferguson and Dunning, 1986), in the present study, inhibition of ACC synthase activity would be expected to occur after 2 days of treatment and to result in complete inhibition of ethylene evolution in all treated flowers. Inhibition of ethylene biosynthesis may therefore occur through time- and concentration-dependent inhibition of the biosynthesis of ACC synthase rather than of its catalysis.

It is not yet known whether the effect of aminotriazole on floral senescence is specific to inhibition of ethylene action or results from an herbicidal activity of aminotriazole, such as promiscuous inhibition of protein biosynthesis. It is clear, however, that between 2 and 4 days after harvest, treated carnations undergo a profound physiological change in that they lose their ability to perceive and therefore to respond to exogenous ethylene. Although the lag time required for complete inhibition of ethylene action suggests a general inhibition of protein synthesis and metabolism, indirect evidence indicates that some specific inhibition of molecular species required for ethylene action may be involved in this response to aminotriazole. As an herbicide, 

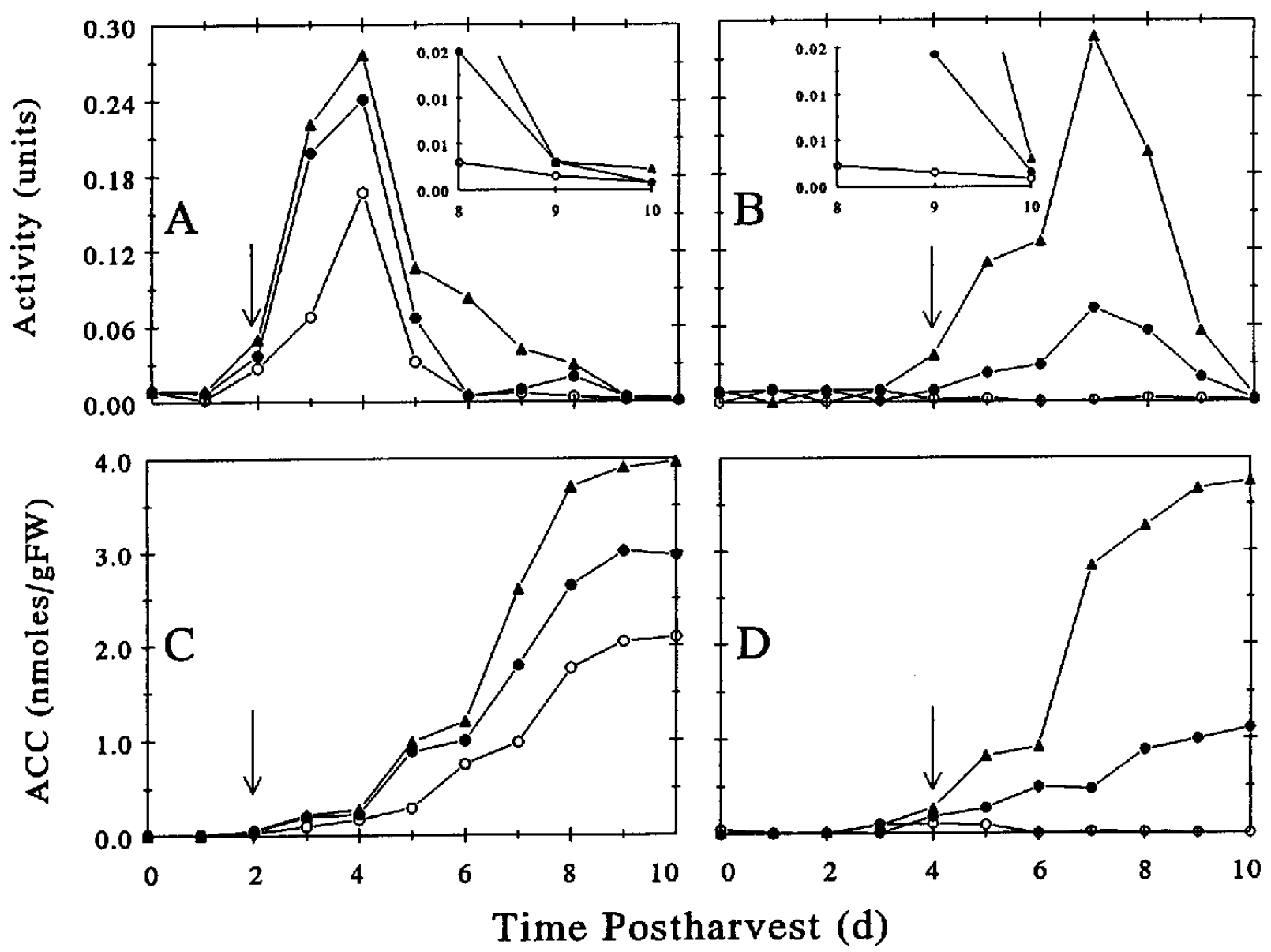

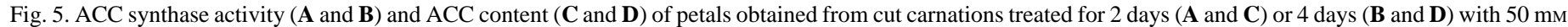

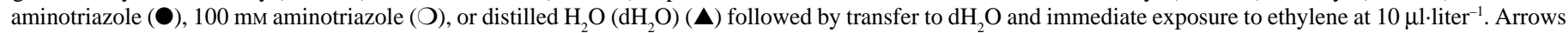
indicate the time of the simultaneous transfer of treated flowers to $\mathrm{dH}_{2} \mathrm{O}$ and imposition of ethylene treatment.

aminotriazole may be applied at concentrations as high as 200 to 400 mm (Rhône-Poulenc Ag Co., 1990). Its mode of action is to inhibit carotenoid biosynthesis, resulting in chlorophyll photooxidation and subsequent disruption of chloroplast structure (Cremlyn, 1991). Such conditions are not applicable in the present study, since the carnations used in all experiments were achlorophyllus and experiments were conducted in darkness. In addition, no lightinduced bleaching of leaves or stems occurred in treated check flowers kept in the laboratory under ambient light (Altman, 1991). Aminotriazole shares the heterocyclic $1 H$-1,2,4-triazole moiety in common with other triazole plant growth regulators, such as paclobutrazol, triadimenol, tridimefon, or propiconizole (Davis, 1988; Goatley and Schmidt, 1990), and is known to stimulate plant growth at low concentrations (Cremlyn, 1991). It is therefore unlikely that the effects of aminotriazole on inhibition of floral senescence were entirely due to an herbicidal action of the compound.

Since aminotriazole does not inhibit all protein biosynthesis (Amory et al., 1992), electrophoretically resolved soluble protein profiles indicated no significant differences between aminotriazole treated flowers and controls at 2 and 4 days of treatment (Altman, 1991). Further, general protein inhibition was not evident in flowers treated with $50 \mathrm{~mm}$ aminotriazole for 4 days. Such flowers exhibited ACC synthase (Figs. 4b and 5b) and ACC oxidase activity in that ACC accumulation (Figs. 4d and 5d) and the conversion of ACC to ethylene (Fig. 1b) was observed. In these same flowers, however, the characteristic events of ethylene action, including ethylene autocatalysis, induction of the respiratory climacteric (Fig. 3), and irreversible petal in-rolling (Altman and Solomos, 1993), were inhibited. The inhibitory effects of 4 days of $50 \mathrm{~mm}$ aminotriazole treatment on ethylene action may therefore proceed by inhibiting the biosynthesis of ethylene receptors or of the molecular species responsible for signal transduction after the interaction of an ethylene and a receptor molecule. If the ability of aminotriazole to act as a temporally mediated inhibitor of ethylene action is borne out, the compound may be useful in identifying the molecular species that constitute the ethylene receptor or that are involved in the events of signal transduction leading to ethylene action.

\section{Literature Cited}

Abeles, F.B., P.W. Morgan, and M.E. Saltveit. 1992. Ethylene in plant biology. 2nd ed. Academic Press, New York. p. 178-181.

Altman, S.A. 1991. Catalase activity, protein accumulation, and expression during senescence of carnations and in response to inhibitors of ethylene synthesis or action. PhD diss. Univ. of Maryland, College Park. Altman, S.A. and T. Solomos. 1993. 3-Amino-1,2,4-triazole prolongs carnation vase life. HortScience 28:201-203.

Amory, A.M., L. Ford, N.W. Pammenter, and C.F. Cresswell. 1992. The use of 3-amino-1,2,4-triazole to investigate the short-term effects of oxygen toxicity on carbon assimilation by Pisum sativum seedlings. Plant Cell Environ. 15:655-663.

Bleeker, A.B., M.A. Estelle, C. Somerville, and H. Kende. 1988. Insensitivity to ethylene conferred by a dominant mutation in Arabidopsis thaliana. Science 241:1086-1089. 
Cremlyn, R.J. 1991. Agrochemicals: Preparation and mode of action. Wiley, New York. p. 247.

Davis, T.D. 1988. Triazole growth regulators, p. 83-105. In: J. Janick (ed.). Horticultural reviews. vol. 10. Timber Press, Portland, Ore.

Ferguson, I.B. and S.J. Dunning. 1986. Effect of 3-amino-1,2,4-triazole, a catalase inhibitor, on peroxide content of suspension cultured pear fruit cells. Plant Sci. 43:7-11.

Goatley, J.M. and R.E. Schmidt. 1990. Anti-senescence activity of chemicals applied to Kentucky bluegrass. J. Amer. Soc. Hort. Sci. 115:654-656.

Hyodo, H. and H. Fujinami. 1989. The effects of 2,5-norbornadiene on the induction of the activity of 1-aminocyclopropane-1-carboxylate synthase and of phenylalanine ammonia-lyase in wounded mesocarp tissue of Cucurbita maxima. Plant Cell Physiol. 30:857-860.

Hyodo, H., Y. Terada, and S. Noda. 1990. Effects of 2,5-norbornadiene and ethylene on the activity of 1-aminocyclopropane-1-carboxylate (ACC) synthase and on increases in the ACC content and rate of ethylene production in petals of cut carnations during senescence. J. Jpn. Soc. Hort. Sci. 59:151-156.

Kidd, G.L. and S.R. Gross. 1984. Specific regulatory interconnection between the leucine and histidine pathways of Neurospora crassa. J. Bacterol. 158:121-127.

Lizada, C. and S.F. Yang. 1979. A simple and sensitive assay for 1aminocyclopropane-1- carboxylic acid. Anal. Biochem. 100:140-145.

McMurchie, E.J., B.W. McGlasson, and J.L. Eaks. 1972. Treatment of fruit with propylene gives information about the biogenesis of ethylene. Nature 237:235-236.

Oeller, P.W., L. Min-Wong, L.P. Taylor, D.A. Pike, and A. Theologis. 1991. Reversible inhibition of tomato fruit senescence by antisense RNA. Science 254:437-439.

Peiser, G. 1986. Levels of 1-aminocyclopropane-1-carboxylic acid (ACC) synthase activity, ACC and ACC-conjugate in cut carnation flowers during senescence. Acta Hort. 181:99-104.

Peñarrubia, L., M. Aguilar, L. Margossian, and R.L. Fischer. 1992. An antisense gene stimulates ethylene hormone production during tomato fruit ripening. Plant Cell 4: 681-687.
Reid, T.J., M.R.N. Murthy, A.A. Sicignano, T. Tanaka, W.D.L. Musick, and M.G. Rossman. 1981. Structure and heme environment of beef liver catalase at 2.4 Å resolution. Proc. Natl. Acad. Sci. USA 78: 4767-4771.

Rhône-Poulenc Ag Company, 1990. Crop protection chemicals reference. 6th ed. Chemical and Pharmaceutical Press, New York. p. 1724$1728 ; 1784-1785$.

Saftner, R.A. and M.N. Martin. 1993. Transport of 1-aminocyclopropane1-carboxylic acid into isolated maize mesophyl vacuoles. Physiol. Plant. 87:535-540.

Sine, C., N. Fisher, and F. Valahovski (eds.). 1991. Farm chemicals handbook. Meister, Willoughby, Ohio. p. C20.

Sisler, E.C. and N. Lallu. 1993. Some effects of diazocyclopentadiene (DACP) on tomato fruit ripening. Plant Physiol. 102(1):169. (Abstr.)

Solomos, T. 1988. Respiration in senescing plant organs: Its nature, regulation and physiological significance, p. 111-145. In: L.D. Noodén and A.C. Leopold (eds.). Senescence and aging in plants. Academic Press, New York.

Theologis, A, T.I. Zarembinski, P.W. Oeller, X. Liang, and S. Abel. 1992. Modification of fruit ripening by suppressing gene expression. Plant Physiol. 100:549-551.

Trewavas, A.J. 1982. Growth substance sensitivity: The limiting factor in plant development. Physiol. Plant. 55:60-72.

Trewavas, A.J. 1991. How do growth substances work? II: Opinion. Plant Cell Environ. 14:1-6.

Woodson, W.R. and K.A. Lawton. 1988. Ethylene-induced gene expression in carnation petals. Plant Physiol. 87:498-503.

Van Loon, L.C. and J. Bruinsma. 1992. The new plant physiology: Molecular approaches to studying hormonal regulation of plant development. Acta Bot. Neerl. 41:1-23.

Ververidis, P. and P. John. 1991. Complete recovery in vitro of ethyleneforming enzyme activity. Phytochemistry 30:725-727.

Yang, S.F. 1985. Biosynthesis and action of ethylene. HortScience 20:4145.

Yu, Y.B., D.O. Adams, and S.F. Yang. 1979. 1-Aminocyclopropanecarboxylate synthase, a key enzyme in ethylene biosynthesis. Arch. Biochem. Biophys. 198:280-286. 